\title{
Clinical Implication of Multi-Parameter Flow Cytometry in Myelodysplastic Syndromes
}

\author{
Carolien Duetz Theresia M. Westers Arjan A. van de Loosdrecht \\ Department of Hematology, Cancer Center Amsterdam, VU University Medical Center, Amsterdam, The Netherlands
}

\section{Keywords}

Myelodysplastic syndromes · Flow cytometry · Diagnosis

\begin{abstract}
Myelodysplastic syndromes (MDS) are a challenging group of diseases for clinicians and researchers, as both disease course and pathobiology are highly heterogeneous. In (suspected) MDS patients, multi-parameter flow cytometry can aid in establishing diagnosis, risk stratification and choice of therapy. This review addresses the developments and future directions of multi-parameter flow cytometry scores in MDS. Additionally, we propose an integrated diagnostic algorithm for suspected MDS.

(c) 2018 The Author(s)

Published by S. Karger AG, Basel
\end{abstract}

\section{Introduction}

The knowledge on and management of myelodysplastic syndromes (MDS) have taken a flight over the past decades; major parts of the pathobiology have been elucidated, several additional diagnostic and prognostic tools implemented and novel therapies discovered [1-
6]. Nevertheless, MDS are still a challenging group of diseases, mostly due to their extensive heterogeneity and often non-clear-cut diagnosis [7, 8]. Hence, several questions are raised by clinicians treating MDS-patients: How certain is this MDS-diagnosis? Is this patient at risk for leukemic transformation or bone marrow failure? What is the chance this patient will respond to a certain therapy? This review is based on the lecture from AA van de Loosdrecht at the European Bone Marrow Working group 2017 on multi-parameter flow cytometry (MFC) and gives an overview of how MFC can support clinicians in the work-up of (suspected) MDS patients. Additionally, we address improved implementation of MFC in routine practice and future perspectives.

\section{MFC in MDS}

Multi-parameter flow cytometry is one of the most extensively used techniques in diagnostic laboratory medicine in hematology, for it enables the evaluation of hematopoietic cells on a single cell level. Hematopoiesis in MDS-patients as assessed by MFC can differ from normal

\begin{tabular}{|c|c|}
\hline KARGER & $\begin{array}{l}\text { (C) } 2018 \text { The Author(s) } \\
\text { Published by S. Karger AG, Basel }\end{array}$ \\
\hline $\begin{array}{l}\text { E-Mail karger@karger.com } \\
\text { www.karger.com/pat }\end{array}$ & $\begin{array}{l}\text { This article is licensed under the Creative Commons Attribution- } \\
\text { NonCommercial-NoDerivatives } 4.0 \text { International License (CC BY- } \\
\text { NC-ND) (http://www.karger.com/Services/OpenAccessLicense). } \\
\text { Usage and distribution for commercial purposes as well as any dis- } \\
\text { tribution of modified material requires written permission. }\end{array}$ \\
\hline
\end{tabular}

Carolien Duetz

Department of Hematology, Cancer Center Amsterdam

VU University Medical Center, De Boelelaan 1117

NL-1081 HV Amsterdam (The Netherlands)

E-Mail c.duetz@vumc.nl 
Table 1. MFC parameters of interest for MDS

\begin{tabular}{|c|c|c|c|c|c|c|c|}
\hline \multicolumn{2}{|l|}{ Progenitors } & \multicolumn{2}{|l|}{ Neutrophils } & \multicolumn{2}{|l|}{ Monocytes } & \multicolumn{2}{|c|}{ Erythroid lineage } \\
\hline CD34 & $\begin{array}{l}\text { Increase in \% or } \\
\text { abnormal expression }\end{array}$ & SSC & Decreased & CD13 & $\begin{array}{l}\text { Lack of or } \\
\text { abnormal } \\
\text { expression }\end{array}$ & CD71 & $\begin{array}{l}\text { Decreased or } \\
\text { heterogeneous } \\
\text { expression }\end{array}$ \\
\hline $\begin{array}{l}\mathrm{CD} 34+/ \mathrm{CD} 10+ \\
\text { or CD34+ and } \\
\text { CD19+ }\end{array}$ & Decrease in \% & CD11b & $\begin{array}{l}\text { Lack of or } \\
\text { abnormal } \\
\text { expression }\end{array}$ & CD14 & $\begin{array}{l}\text { Lack of or } \\
\text { abnormal } \\
\text { expression }\end{array}$ & CD36 & $\begin{array}{l}\text { Decreased or } \\
\text { heterogeneous } \\
\text { expression }\end{array}$ \\
\hline CD45 & Abnormal expression & CD13 & $\begin{array}{l}\text { Lack of or } \\
\text { abnormal } \\
\text { expression }\end{array}$ & CD16 & $\begin{array}{l}\text { Lack of or } \\
\text { abnormal } \\
\text { expression }\end{array}$ & CD117 & $\begin{array}{l}\text { Abnormal } \\
\text { frequency }\end{array}$ \\
\hline CD117 & Abnormal expression & CD33 & $\begin{array}{l}\text { Lack of or } \\
\text { abnormal } \\
\text { expression }\end{array}$ & CD33 & $\begin{array}{l}\text { Lack of or } \\
\text { abnormal } \\
\text { expression }\end{array}$ & CD105 & $\begin{array}{l}\text { Abnormal } \\
\text { frequency }\end{array}$ \\
\hline SSC & Abnormal granularity & CD16 & Delayed expression & CD11b & $\begin{array}{l}\text { Abnormal } \\
\text { expression }\end{array}$ & & \\
\hline CD13 & $\begin{array}{l}\text { Overexpression or lack } \\
\text { of expression }\end{array}$ & CD10 & Lack of expression & HLA-DR & $\begin{array}{l}\text { Abnormal } \\
\text { expression }\end{array}$ & & \\
\hline CD33 & $\begin{array}{l}\text { Overexpression or lack } \\
\text { of expression }\end{array}$ & CD56 & Expression & CD56 & Overexpression & & \\
\hline HLA-DR & $\begin{array}{l}\text { Overexpression or lack } \\
\text { of expression }\end{array}$ & Subsets & $\begin{array}{l}\% \text { abnormal } \\
\text { distribution of } \\
\text { mature and } \\
\text { immature subsets }\end{array}$ & SSC & $\begin{array}{l}\text { Decreased } \\
\text { or increased }\end{array}$ & & \\
\hline CD5 & $\begin{array}{l}\text { Expression on myeloid } \\
\text { progenitors }\end{array}$ & $\%$ & $\begin{array}{l}\text { As a ratio to } \\
\text { lymphocytes }\end{array}$ & Subsets & & $\begin{array}{l}\% \text { abno } \\
\text { mature } \\
\text { subsets }\end{array}$ & $\begin{array}{l}\text { distribution of } \\
\text { mmature }\end{array}$ \\
\hline CD7 & $\begin{array}{l}\text { Expression on myeloid } \\
\text { progenitors }\end{array}$ & $\mathrm{CD} 13 / \mathrm{CD} 11 \mathrm{~b}$ & Altered pattern & HLA-DR/11b & $\begin{array}{l}\text { Altered } \\
\text { pattern }\end{array}$ & & \\
\hline CD19 & $\begin{array}{l}\text { Expression on myeloid } \\
\text { progenitors }\end{array}$ & CD13/CD16 & Altered pattern & CD36/CD14 & $\begin{array}{l}\text { Altered } \\
\text { pattern }\end{array}$ & & \\
\hline CD56 & $\begin{array}{l}\text { Expression on myeloid } \\
\text { progenitors }\end{array}$ & CD15/CD10 & Altered pattern & & & & \\
\hline CD11b & $\begin{array}{l}\text { Expression on myeloid } \\
\text { progenitors }\end{array}$ & & & & & & \\
\hline CD15 & Overexpression & & & & & & \\
\hline
\end{tabular}

MFC, multi-parameter flow cytometry; MDS, myelodysplastic syndrome; SSC, side scatter.

by an altered antigen expression, frequency of cell subsets and scatter properties. Currently, many aberrancies of the progenitor cells, the myelomonocytic lineage and the erythroid lineage are well described. Altered immunophenotypic profiles have been shown useful in diagnosis, risk stratification and therapy guidance of MDS-patients. The International Working Group for FC in MDS (IMDSFlow) of the European Leukemia Net (ELNet) published guidelines for MFC in MDS [7, 9, 10]. Table 1 summarizes the flow cytometric characteristics per cell compartment that are recommended for evaluation by IMDSFlow.

\section{Flow Cytometric Aberrancies per Cell Subset}

\section{The Progenitor Cell Compartment}

Quantifying blasts is of importance in MDS, as blast percentage by morphology discriminates MDS from acute myeloid leukemia (AML) [6]. Moreover, morphologic blast counts subdivide MDS in prognostic relevant sub categories according to World Health Organization classification as well as according to the revised International Prognostic Scoring System (IPSS-R) $[5,6]$. MFC enables quantification of immature cells. However, multiple studies have shown that although 
the percentages of immature cells between morphology and MFC correlate, they are not interchangeable [1113]. One of the possible causes is hemodilution, leading to an underestimation of immature cell percentage in the bone marrow compartment by MFC. Hence, MFC quantification of immature cells cannot substitute morphologic blast count. Nevertheless, MFC gives insight in whether immunophenotype of immature cells differs from normal [14]. For instance, myeloid progenitors can express lymphoid lineage-specific markers (Fig. 1), have altered granulation reflected by the side scatter and have increased, decreased or aberrantly distributed marker expression. What is more, also B-cell progenitors can be quantitatively affected in MDS; absence or decrease in progenitor-B-cells is a frequently observed feature $[15,16]$. However, this is not a MDS-specific feature and is commonly seen in other diseases and elderly patients.

\section{The Maturing Myelomonocytic Lineage}

Neutrophils in MDS are often decreased in frequency and hampered in function. Flow cytometry can detect aberrancies in neutrophils. Classical aberrancies in MDS are a decreased SSC, reflecting the morphologic paradigm of hypogranulation, and altered maturation patterns (Fig. 1).

Monocytic dysplasia is difficult to assess by morphology, for monocyte frequency is low. Flow cytometry, however, is eminently useful in studying less frequent populations and hence, in monocytic evaluation. A frequently observed aberrancy on monocytes is an expression of CD56 (Fig. 1). However, the activation and regeneration of bone marrow can also induce expression of CD56. Having knowledge on the clinical context of patients is therefore of importance. The optimal cut-off for the percentage of CD56 is yet to be determined. In case of (borderline) monocytosis in bone marrow or peripheral blood, chronic myelomono-

Fig. 1. Examples of myelodysplastic syndrome (MDS)-associated immunophenotypic aberrancies. Healthy bone marrow samples are depicted in the left column, MDS cases in the right column. The first row depicts aberrant lineage-infidelity expression of CD5 on myeloid progenitors in MDS. The aberrant CD5+ cells are depicted in red. Myeloid progenitors are defined as CD45dim, SSC low-intermediate, CD34+ and/or CD117+. In the second row, the MDS case displays an aberrant neutrophil maturation profile with decreased expression of CD11b in a subset of maturing neutrophils. The green arrow indicates neutrophil maturation in healthy individuals. Neutrophils are defined as CD45dim, SSC intermedi- cytic leukemia (CMML) or CMML-like MDS should be considered. The evaluation of peripheral blood monocyte repartition by MFC is highly recommended in case of (borderline) monocytosis. Monocytes can be divided into 3 subtypes: classical CD14 positive/CD16 negative, intermediate CD14 positive/CD16 positive and nonclassical CD14low/CD16 positive. Monocytes in CMML are preferentially classical monocytes. The latter can be used as a diagnostic tool. Selimoglu-Buet et al. [17] showed that using a cut-off of $>94 \%$ classical monocytes, discriminates CMML from reactive monocytosis with a specificity of $95.1 \%$ and a sensitivity of $91.9 \%$ [17-20].

\section{The Erythroid Lineage}

Over 80 percent of MDS-patients have anemia at the time of diagnosis as a result of disturbed erythroid maturation. The first markers used to assess aberrant erythroid phenotype were CD235a and CD71 expression [21]. Currently, the most used and validated parameters are expression and distribution of CD36 and CD71. Also, relevant to address aberrant erythroid phenotype are CD34, CD117 and CD105 (Fig. 1) [10]. Notably, when studying the erythroid lineage, the type of lysing procedure used during sample processing for MFC, or no lysing, is of importance, as some stringent lysing methods negatively impact the frequency of erythroid precursor subsets $[10$, 22].

\section{Additional Cell-Subsets of Interest}

Megakaryocytic dysplasia is one of the most MDSspecific findings by morphology. Megakaryocytes, however, proved difficult to analyze by MFC due to frequency, size and cellular complexity. Possibly, platelet abnormalities may reflect dysplasia of megakaryocytes and can therefore be used as a substitute [21]. Sandes et al. [23] compared peripheral blood platelets in MDS $(n=44)$ with healthy controls thereby demon-

ate-high. The third row demonstrates aberrant CD56 expression on monocytes in MDS. The aberrant cells are depicted in red. Monocytes are defined as CD45 dim-bright, SSC intermediate. The MDS case in the last row shows aberrant erythroid maturation with an increased heterogeneity of CD71 expression and an expansion of CD117+ cells (depicted in orange). The cells depicted in red have CD71dim expression, which contributes to the increased heterogeneity of CD71 expression. This is rarely seen in healthy individuals. Erythroid progenitors are defined as CD45dim-negative, SSC intermediate-low, CD33-, CD71+.

(For figure 1 see next page.)
16

Pathobiology 2019;86:14-23

DOI: $10.1159 / 000490727$
Duetz/Westers/van de Loosdrecht 

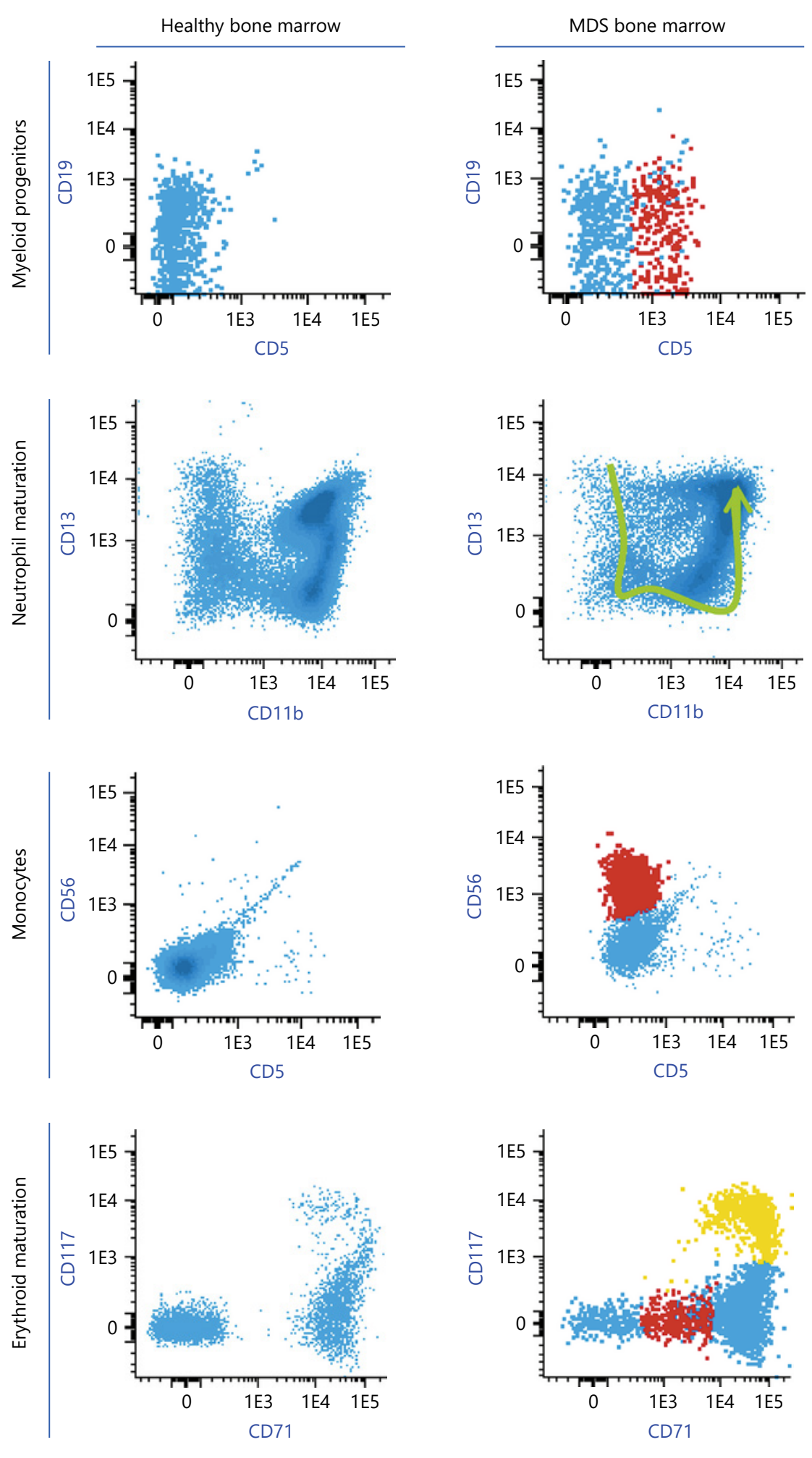
strating differences in scatter, expression of CD34, CD36, CD42a and CD61. These findings have to be extensively validated due to confounders such as activation and inflammation before implementation in routine practice.

Several other hematopoietic cell subsets, involved in the dysplastic clone and/or in the immunopathogenesis of MDS, have been described, including aberrancies in mast cells, changes of frequency in plasmacytoid dendritic cells, myeloid dendritic cells ( $\mathrm{mDC} 1$ and $\mathrm{mDC} 2)$, myeloid-derived suppressor cells (MDSC) and T cell subsets $[24,25]$. Increased frequencies of MDSCs and T-regulatory cells are thought to reflect an immunosuppressive environment in high risk MDS $[2,26]$. The immunophenotype of MDSCs in humans, however, is not yet fully agreed upon [27].

\section{Considerations and Pitfalls}

Technical considerations and pitfalls are described in detail by IMDSFlow and others $[9,28]$. In short, to conduct a reliable MFC experiment, several aspects have to be taken into consideration, including sample handling, instrument settings and interpretation of results. First, the ELNet guidelines favour collecting bone marrow in tubes with heparin anticoagulant, as EDTA is known to influence marker expression such as CD11b. However, more important than the preference for heparin is standardized processing including anticoagulant and knowledge of the possible drawbacks of for instance EDTA. Second, time to processing of bone marrow is important (preferentially $<24 \mathrm{~h}$ after aspiration) as an increase in SSC on neutrophils and a decrease in numbers of CD14 positive monocytes has been observed in older samples. Subsequently, lysing procedures may influence marker expression and population size, especially with respect to the erythroid lineage as discussed above. Hereto, within a single center, standard processing including a uniform lysing procedure, or even refraining from a lysing procedure when analyzing the erythroid lineage, is essential.

Flow cytometry panels should contain optimal marker combinations to distinguish populations, evaluate maturation patterns and assess aberrant expression. Additionally, constructing a panel with minimal spectral overlap and proper compensation, measured on a flow cytometer with optimized instrument settings is essential $[9,28]$. The Euroflow consortium compiled an MFCpanel for MDS/AML [29]. It contains most of the advised markers and combinations from IMDSFlow guidelines [30]. Several groups designed alternative MFC-pan- els for MDS (online suppl. Table A; see www.karger. com/doi/10.1159/000490727).

Analysis of MFC data has to be performed by trained professionals with extensive knowledge on immunophenotypic profiles of normal bone marrow and other hematopoietic diseases. Examples of normal bone marrow flow cytometry can be found at the bone marrow MFC Atlas at the ELNet website [31]. Several findings can be misleading for less experienced staff. Examples of pitfalls are distinguishing low expression of CD33 due to a regularly occurring splicing variant (polymorphism) from aberrant low expression in MDS and distinguishing aberrant loss of marker expression from apoptosis-induced changes. In conclusion, optimal MFC analysis includes uniform sample handling, standardized instrument settings and knowledge on normal and pathological hematopoiesis.

\section{Clinical Utility of MFC}

Multi-parameter flow cytometry can be clinically applied for diagnosis, risk stratification and therapy monitoring. For these applications, several so-called MFC scores have been developed. MFC scores are generally based on the same concept: flow cytometric aberrancies encountered in MDS are scored and combined to establish either diagnosis or a risk profile. Typically, a high number of aberrancies represents a higher diagnostic accuracy and a higher risk for leukemic transformation. Substantial differences in MFC-scores are encountered in combination of markers, the amount of parameters (from single to several) and the weight assigned to each parameter $[30,32,33]$.

\section{MFC-Scores for Diagnosis}

Myelodysplastic syndromes can be difficult to distinguish from other (non)clonal causes of cytopenia. Dysplasia according to cytomorphology and histopathology combined with cytogenetic aberrancies is considered the gold standard [6]. However, 50\% of MDS-cases have normal cytogenetics and assessment of dysplasia is not always clear-cut and known to be subjected to inter-user variability [34]. Moreover, dysplasia can be caused by several other factors such as intoxications and medication. In 2012, the ELNet added MFC-scores as a recommended tool in the diagnostic work-up of MDS [35]. These guidelines were updated recently and the additive value of MFC is continuously acknowledged [7]. The latest edition of the World Health Organization Classification of $\mathrm{Tu}$ -
18

Pathobiology 2019;86:14-23 DOI: $10.1159 / 000490727$
Duetz/Westers/van de Loosdrecht 
mours of Haematopoietic and Lymphoid Tissues contains a similar recommendation [36].

Over a dozen diagnostic-MFC scores have been developed since Stetler-Stevenson et al. [21] published the first score in 2001. Here, we discuss the Ogata-score, the RED-score, the erythroid parameters of the IMDSflow and the Integrated Flow score (iFCs) including the Flow Cytometric Scoring System (FCSS) of Wells et al. [30, 33]. The Ogata score is a 4-parameter score consisting of the SSC on neutrophils related to SSC of lymphocytes, percentage of progenitor B-cells within the CD34+ compartment, the percentage of CD34+ myeloid progenitors of nucleated cells and the CD45 expression on CD34+ progenitors related to that of lymphocytes. This score displays a sensitivity of $72 \%$ and a specificity of $93 \%$ in low risk MDS-patients and cytopenic controls respectively $[32,37]$. The Ogata score is practical and relatively simple; however, sensitivity has proven to be insufficient in low risk MDS. Over the past years, 2 studies to evaluate the erythroid lineage have been published by Mathis et al. [38] and IMDSflow. They first developed the REDscore that includes the variation in fluorescence intensity of CD36 and CD71 on the erythroid lineage and haemoglobin levels [38]. Combining the RED-score with the Ogata score shows a sensitivity of 88 percent and a specificity of $89 \%$ [38]. The second study concerns the erythroid parameters recommended by IMDSFlow: CD36 and CD71 distribution and CD36 expression on the erythroid lineage and the percentage CD117+ erythroid precursors. If combined with the Ogata score, it has a sensitivity of $86 \%$ and a specificity of $95 \%$. Hence, combining erythroid parameters with the Ogata score increases sensitivity. Integrating the Ogata-score, Wells' FCSS and the IMDSFlow erythroid markers, into the socalled iFCs showed $80 \%$ sensitivity and $95 \%$ specificity. The FCSS evaluates the (im)mature myelomonocytic lineage and has $75 \%$ sensitivity and $100 \%$ specificity when used independently $[10,33,39]$. A multicenter study within the IMDSFlow WG is launched to evaluate which parameters are most powerful for separating MDS from other causes of cytopenia.

Diagnostic MFC-scores are thought to have the highest additive value in suspected MDS with normal cytogenetics and inconclusive bone marrow morphology $[40,41]$. In these patients, MFC may circumvent the need for a second diagnostic bone marrow aspirate and reduce the risk of false positive or false negative diagnosis. Additionally, MFC-scores might aid in managing several recently defined MDS-related syndromes, such as idiopathic dysplasia of undetermined signifi-

Flow Cytometry in MDSs cance, clonal hematopoiesis of indeterminate potential and clonal cytopenia of undetermined significance [42-44].

\section{MFC Scores in Risk Stratification}

Myelodysplastic syndromes are characterized by a heterogeneous disease course, ranging from a stable, smouldering cytopenia without need for treatment to rapid bone marrow failure or leukemic transformation. The IPSS-R is the most refined tool for risk stratification [5]. However, in the low risk category patients, AML evolution is observed up to $25 \%$ in 10 years and patients categorized as high risks do not always develop AML, indicating the need for some refinement. As mentioned above, most MFC scores have both diagnostic and prognostic values. Several have proven to be of prognostic value within IPSS-R risk groups [30, 45]. For example, Della Porta et al. [45] have shown that the Ogata-score has prognostic value in low-risk MDS within IPSS-R subcategories. Moreover, we and others have shown that the number of aberrancies in the FCSS is associated with transfusion dependency, earlier progression of disease, leukemia-free survival and overall survival. A 3-parameter score developed solely for prognosis by Alhan et al. [46] has prognostic value beyond the IPSS-R low risk category. They combined CD13 expression on monocytes with sideward light scatter and CD117 expression of myeloid progenitor cells [46]. Other parameters that have negative prognostic value in the lower risk categories are a low progenitor Bcell abundance combined with an increase in regulatory T- cells. Moreover, Chen et al. [47] showed that an increased CD200 expression on CD33+ bone marrow cells is a poor-prognostic parameter independent of the IPSS.

\section{Choice of Treatment and Therapy Monitoring}

Few studies have looked into the potential of MFC as a tool for therapy selection and guidance. The first MFC-score with therapy guiding potential was the FCSS, namely, in predicting outcome after stem cell transplantation [30]. Westers et al. [48] showed that having aberrant progenitors negatively correlates with response to growth factor treatment. The same relation for response to azacitidine in intermediate- 2 and high-risk MDS patients was shown [49]. Another interesting implementation for MFC is therapy monitoring. Persistence or clearance of FC aberrancies may reflect response to therapy. A recent study showed that MDS with isolated $\operatorname{del}(5 \mathrm{q})$ has a typical immunophenotypic profile that can be used to evaluate treatment response and support treatment decisions [50]. 
Fig. 2. Proposal of a diagnostic algorithm in cytopenic patients. The displayed algorithm demonstrates how MFC can aid in the diagnosis of cytopenic patients suspected for MDS. First, cytopenic patients with MDS-specific aberrancies either according to morphology or cytogenetics, can be assigned to the MDS category. MDS-specific morphologic aberrancies are for example an increase in blast count and the presence of $>15 \%$ ring sideroblasts. MDS-specific cytogenetic aberrancies are described in "The 2008 revision of the WHO classification of myeloid neoplasms and acute leukemia" [62]. Second, patients who have a clear other cause of cytopenia based on these diagnostic tools are considered "no MDS." In the remaining patients, MFC contributes to the diagnosis, that is, based on the results of the MFC (e.g., the iFCs), patients are either diagnosed with MDS or classified in the no-MDS or FU-needed group. Note that these patients would otherwise have been classified as inconclusive. MFC, multi-parameter flow cytometry; MDS, myelodysplastic syndromes; WHO, World Health Organization; iFCs, integrated flow score; FU, follow-up.

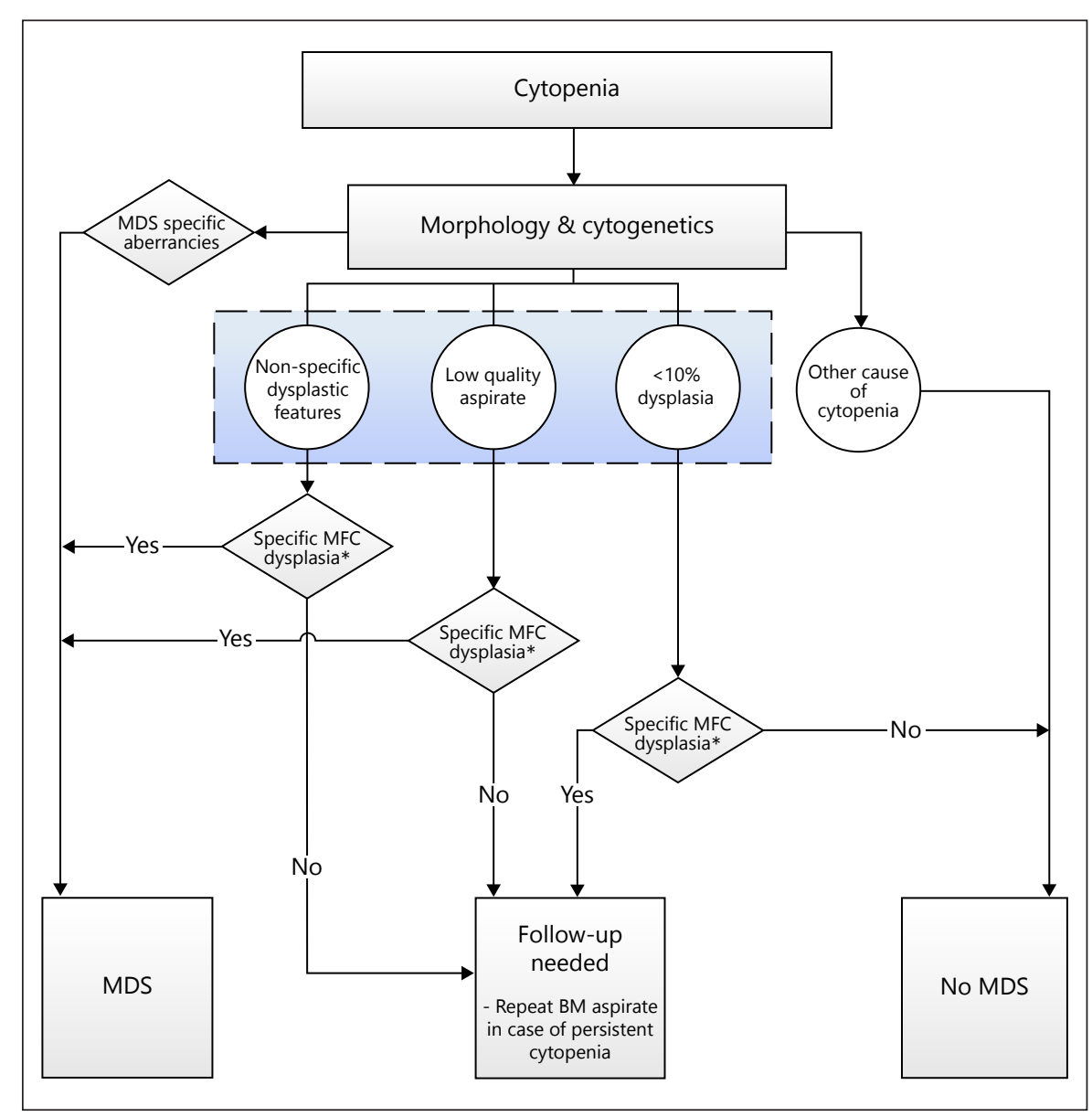

\section{Future Perspectives}

\section{Implementation in Routine Practice}

Multi-parameter flow cytometry is a valuable tool in the complicated diagnostic process of MDS and has additive value in risk stratification and therapy guidance. However, its clinical value is not fully reflected by the degree of implementation in routine practice. One of the causes may be the amount of parameters of interest and the variety of MFC scores. IMDSFlow has published clear guidelines on which markers are the most relevant [9]. However, this recommended marker panel includes a vast amount of markers resulting in a complex and costly analysis. Ideally, minimal MFC panels for diagnosis, prognosis and treatment guidance should be compiled by selecting the most powerful markers from large data sets.

Another improvement to increase diagnostic implementation could be a clear flowchart for the diagnostic work-up of cytopenic patients suspected for having MDS including MFC. In Figure 2, we propose a first draft (Fig. 2). This flowchart shows how clinicians can implement diag- nostic MFC scores. Moreover, it demonstrates that MFC will have the most impact in cytopenic cases without specific MDS morphological dysplasia and cytogenetic aberrancies. Yet, the accuracy of this diagnostic flowchart will depend on the sensitivity and specificity of the MFC score used. We propose the use of a validated score, such as the iFCs or the Ogata score combined with IMDSFlow erythroid parameters [10,33]. Validation of the proposed diagnostic flowchart is required before implementation.

Regarding risk-stratification, the development of a prognostic scoring system combining clinical parameters and morphology with results from flow cytometry and NGS, similar as was recently published for AML, is of interest [51].

Another cause for the limited implementation of MDS-MFC in routine practice is, presumably, the challenging and time-consuming analysis. Currently, most flow cytometry data is analyzed manually: 2D-plots are inspected visually and cells are assigned to subpopulations based on current knowledge. Over the past decade computational knowledge and power has increased and 
several automated visualization, clustering and analysis tools have been developed $[52,53]$. Implementation could decrease the time and expertise needed for analysis and more importantly the subjectivity that is inherent to manual analysis. Most visualization tools apply dimensionality reduction to comprehensively visualize multi-dimensional data in a two-dimensional manner. Jafari et al. [54] applied a visualization method on MFC data of MDS patients and healthy patients called radar-plots. They showed that this method is able to group cells in accordance with manual gating strategies. Moreover, the radar plots show clear differences between MDS bone marrow and healthy bone marrow and hence, may provide a faster and less subjective way of analyzing. In other hematopoietic malignancies, several automated analysis tools for population identification, diagnostics and detection of minimal residual disease (MRD) are being developed that may provide diagnostic and/or prognostic information with high accuracy. For example, the detection of chronic lymphocytic leukemia, multiple myeloma cells and MRD in multiple myeloma can be automated, as is the case for MRD analysis and subgrouping in AML [55-58]. Another interesting application of automated data analysis is risk stratification. The latest challenge of "FlowCAP," an initiative to improve computational flow cytometry data analysis, showed several algorithms that accurately predicted the time to progression from HIV to AIDS using flow cytometric data [59]. In short, there is a broad range of possibilities for automated analysis, although implementation in MDS is currently limited.

Further improvements to MFC-scores could be achieved by the application of recent technical developments that might give us more insight in specific immunophenotypic profiles of MDS. For example, the increasing number of parameters per cell that can be measured simultaneously using either flow cytometry or mass cytometry can increase the chance of discovering novel MDS-specific markers and cell subsets.

\section{Conclusion}

Multi-parameter flow cytometry supports clinicians by answering challenging questions dealing with the management of MDS-patients, as it is useful in diagnosis, risk stratification and therapy guidance. Further research is required to compile optimal and simple panels that can be easily implemented in routine laboratory medicine. Additionally, embracing novel techniques such as automated analysis and high-dimensional single-cell analysis will, potentially increase the clinical impact of MFC.

\section{Disclosure Statement}

The authors declare that there are no conflicts of interest to disclose.

\section{References}

1 Xu Y, Li Y, Xu Q, Chen Y, Lv N, Jing Y, Dou L, Bo J, Hou G, Guo J, Wang X, Wang L, Li Y, Chen C, Yu L, et al: Implications of mutational spectrum in myelodysplastic syndromes based on targeted next-generation sequencing. Oncotarget 2017;8:82475-82490.

2 Lambert C, Wu Y, Aanei C: Bone marrow immunity and myelodysplasia. Frontiers in Oncology 2016;6:172.

3 Platzbecker U, Germing U, Götze KS, Kiewe P, Mayer K, Chromik J, Radsak M, Wolff T, Zhang X, Laadem A, Sherman ML, Attie KM, Giagounidis A: Luspatercept for the treatment of anaemia in patients with lower-risk myelodysplastic syndromes (PACE-MDS): a multicentre, open-label phase 2 dose-finding study with long-term extension study. Lancet Oncol 2017;18:1338-1347.

4 Talati C, Sallman D, List A: Lenalidomide: myelodysplastic syndromes with $\operatorname{del}(5 \mathrm{q})$ and beyond. Seminars in Hematology 2017;54: 159-166.

5 Greenberg PL, Tuechler H, Schanz J, Sanz G, Garcia-Manero G, Solé F, Bennett JM, Bowen
D, Fenaux P, Dreyfus F, Kantarjian H, Kuendgen A, Levis A, Malcovati L, Cazzola M, Cermak J, Fonatsch C, Le Beau MM, Slovak ML, Krieger O, Luebbert M, Maciejewski J, Magalhaes SM, Miyazaki Y, Pfeilstöcker M, Sekeres M, Sperr WR, Stauder R, Tauro S, Valent P, Vallespi T, van de Loosdrecht AA, Germing U, Haase D: Revised international prognostic scoring system for myelodysplastic syndromes. Blood 2012;120:2454-2465.

6 Arber DA, Orazi A, Hasserjian R, Thiele J, Borowitz MJ, Le Beau MM, Bloomfield CD, Cazzola M, Vardiman JW: The 2016 revision to the World Health Organization classification of myeloid neoplasms and acute leukemia. Blood 2016;127:2391-2405.

7 Valent P, Orazi A, Steensma DP, Ebert BL, Haase D, Malcovati L, van de Loosdrecht AA, Haferlach T, Westers TM, Wells DA, Giagounidis A, Loken M, Orfao A, Lübbert M, Ganser A, Hofmann WK, Ogata K, Schanz J, Béné MC, Hoermann G, Sperr WR, Sotlar K, Bettelheim P, Stauder R, Pfeilstöcker M, Horny HP, Germing U, Greenberg P, Bennett
JM: Proposed minimal diagnostic criteria for myelodysplastic syndromes (MDS) and potential pre-MDS conditions. Oncotarget 2017;8:73483-73500.

8 Dussiau C, Fontenay M: Mechanisms underlying the heterogeneity of myelodysplastic syndromes. Experimental Hematology 2018; 58:17-26.

9 Westers TM, Ireland R, Kern W, Alhan C, Balleisen JS, Bettelheim P, Burbury K, Cullen M, Cutler JA, Della Porta MG, Dräger AM, Feuillard J, Font P, Germing U, Haase D, Johansson U, Kordasti S, Loken MR, Malcovati $\mathrm{L}$, te Marvelde JG, Matarraz S, Milne T, Moshaver B, Mufti GJ, Ogata K, Orfao A, Porwit A, Psarra K, Richards SJ, Subirá D, Tindell V, Vallespi T, Valent $\mathrm{P}$, van der Velden VH, de Witte TM, Wells DA, Zettl F, Béné MC, van de Loosdrecht AA: Standardization of flow cytometry in myelodysplastic syndromes: a report from an international consortium and the European LeukemiaNet Working Group. Leukemia 2012;26:17301741. 
10 Westers TM, Cremers EM, Oelschlaegel U, Johansson U, Bettelheim P, Matarraz S, Orfao A, Moshaver B, Brodersen LE, Loken MR, Wells DA, Subirá D, Cullen M, Te Marvelde JG, van der Velden VH, Preijers FW, Chu SC, Feuillard J, Guérin E, Psarra K, Porwit A, Saft L, Ireland R, Milne T, Béné MC, Witte BI, Della Porta MG, Kern W, van de Loosdrecht AA: Immunophenotypic analysis of erythroid dysplasia in myelodysplastic syndromes. A report from the IMDSFlow working group. Haematologica 2017;102:308-319.

11 Sandes AF, Kerbauy DM, Matarraz S, Chauffaille Mde L, López A, Orfao A, Yamamoto M: Combined flow cytometric assessment of CD45, HLA-DR, CD34, and CD117 expression is a useful approach for reliable quantification of blast cells in myelodysplastic syndromes. Cytometry B Clin Cytom 2013;84: 157-166.

12 Jelic TM, Mellen PF, Zavieh K, Roque JC, Farren SP, Jin B, Ahmad N, Estallila OC, Chang $\mathrm{HH}$ : Correlation between the percentages of myeloblasts in bone marrow obtained by flow cytometry and manual counting on glass slide smears in 74 hematologic patients. Leuk Lymphoma 2002;43:1927-1931.

13 Aldawood AM, Kinkade Z, Rosado FG, Esan OA, Gibson LF, Vos JA: A novel method to assess bone marrow purity is useful in determining blast percentage by flow cytometry in acute myeloid leukemia and myelodysplasia. Ann Hematol Oncol 2015;2:1038.

14 Ogata K, Nakamura K, Yokose N, Tamura H, Tachibana M, Taniguchi O, Iwakiri R, Hayashi T, Sakamaki H, Murai Y, Tohyama K, Tomoyasu S, Nonaka Y, Mori M, Dan K, Yoshida Y: Clinical significance of phenotypic features of blasts in patients with myelodysplastic syndrome. Blood 2002;100:38873896.

15 Sternberg A, Killick S, Littlewood T, Hatton C, Peniket A, Seidl T, Soneji S, Leach J, Bowen D, Chapman C, Standen G, Massey E, Robinson L, Vadher B, Kaczmarski R, Janmohammed R, Clipsham K, Carr A, Vyas P: Evidence for reduced B-cell progenitors in early (lowrisk) myelodysplastic syndrome. Blood 2005; 106:2982-2991.

16 van de Loosdrecht AA, Alhan C, Béné MC, Della Porta MG, Dräger AM, Feuillard J, Font $\mathrm{P}$, Germing U, Haase D, Homburg CH, Ireland R, Jansen JH, Kern W, Malcovati L, Te Marvelde JG, Mufti GJ, Ogata K, Orfao A, Ossenkoppele GJ, Porwit A, Preijers FW, Richards SJ, Schuurhuis GJ, Subirá D, Valent P, van der Velden VH, Vyas $\mathrm{P}$, Westra AH, de Witte TM, Wells DA, Loken MR, Westers TM: Standardization of flow cytometry in myelodysplastic syndromes: report from the first European LeukemiaNet working conference on flow cytometry in myelodysplastic syndromes. Haematologica 2009;94:11241134.

17 Selimoglu-Buet D, Wagner-Ballon O, Saada V, Bardet V, Itzykson R, Bencheikh L, Morabito M, Met E, Debord C, Benayoun E, Nloga
AM, Fenaux P, Braun T, Willekens C, Quesnel B, Adès L, Fontenay M, Rameau P, Droin N, Koscielny S, Solary E, Characteristic repartition of monocyte subsets as a diagnostic signature of chronic myelomonocytic leukemia. Blood 2015;125:3618-3626.

18 Talati C, Zhang L, Shaheen G, Kuykendall A, Ball M, Zhang Q, Lancet JE, Zuckerman KS, List AF, Komrokji R, Moscinski L, Padron E: Monocyte subset analysis accurately distinguishes CMML from MDS and is associated with a favorable MDS prognosis. Blood 2017; 129:1881-1883.

19 Selimoglu-Buet D, Badaoui B, Benayoun E, Toma A, Fenaux P, Quesnel B, Etienne G, Braun T, Abermil N, Morabito M, Droin N, Solary E, Wagner-Ballon O: Accumulation of classical monocytes defines a subgroup of MDS that frequently evolves into CMML. Blood 2017;130:832-835.

20 Vazquez R, Roussel M, Badaoui B, Freynet N, Tarfi S, Solary E, Selimoglu-Buet D, WagnerBallon O: High sensitivity of the Hematoflow $^{\mathrm{TM}}$ solution for chronic myelomonocytic leukemia screening. Cytometry B Clin Cytom 2017, Epub ahead of print.

21 Stetler-Stevenson M, Arthur DC, Jabbour N, Xie XY, Molldrem J, Barrett AJ, Venzon D, Rick ME: Diagnostic utility of flow cytometric immunophenotyping in myelodysplastic syndrome. Blood 2001;98:979.

22 Wangen JR, Eidenschink Brodersen L, Stolk TT, Wells DA, Loken MR: Assessment of normal erythropoiesis by flow cytometry: important considerations for specimen preparation. Int J Lab Hematol 2014;36:184-196.

23 Sandes AF, Yamamoto M, Matarraz S, Chauffaille Mde L, Quijano S, López A, Oguro T, Kimura EY, Orfao A: Altered immunophenotypic features of peripheral blood platelets in myelodysplastic syndromes. Haematologica 2012;97:895-902.

24 van Leeuwen-Kerkhoff N, Lundberg K, Westers TM, Kordasti S, Bontkes HJ, de Gruijl TD, Lindstedt M, van de Loosdrecht AA: Transcriptional profiling reveals functional dichotomy between human slan+ non-classical monocytes and myeloid dendritic cells. J Leukoc Biol 2017;102:1055-1068.

25 Saft L, Björklund E, Berg E, Hellström-Lindberg E, Porwit A: Bone marrow dendritic cells are reduced in patients with high-risk myelodysplastic syndromes. Leuk Res 2013;37:266273.

26 Kittang AO, Kordasti S, Sand KE, Costantini B, Kramer AM, Perezabellan P, Seidl T, Rye KP, Hagen KM, Kulasekararaj A, Bruserud Ø, Mufti GJ: Expansion of myeloid derived suppressor cells correlates with number of $\mathrm{T}$ regulatory cells and disease progression in myelodysplastic syndrome. Oncoimmunology 2016:5:e1062208.

27 Ostrand-Rosenberg S, Fenselau C: MyeloidDerived Suppressor Cells: Immune-Suppressive Cells That Impair Antitumor Immunity and Are Sculpted by Their Environment. J Immunol 2018;200:422-431.
28 Alhan C, Westers TM, Cremers EM, Cali C, Ossenkoppele GJ, van de Loosdrecht AA: Application of flow cytometry for myelodysplastic syndromes: Pitfalls and technical considerations. Cytometry B Clin Cytom 2016;90: 358-367.

29 van Dongen JJ, Lhermitte L, Böttcher S, Almeida J, van der Velden VH, Flores-Montero J, Rawstron A, Asnafi V, Lécrevisse Q, Lucio P, Mejstrikova E, Szczepański T, Kalina T, de Tute R, Brüggemann M, Sedek L, Cullen M, Langerak AW, Mendonça A, Macintyre E, Martin-Ayuso M, Hrusak O, Vidriales MB, Orfao A: EuroFlow antibody panels for standardized n-dimensional flow cytometric immunophenotyping of normal, reactive and malignant leukocytes. Leukemia 2012;26: 1908-1975.

30 Wells DA, Benesch M, Loken MR, Vallejo C, Myerson D, Leisenring WM, Deeg HJ: Myeloid and monocytic dyspoiesis as determined by flow cytometric scoring in myelodysplastic syndrome correlates with the IPSS and with outcome after hematopoietic stem cell transplantation. Blood 2003;102:394-403.

31 ELNet, Flow cytometry atlas. https://www. leukemia-net.org/content/diagnostics/diagnostics/flow_cytometry_atlas/index_eng. html 2009.

32 Della Porta MG, Picone C, Pascutto C, Malcovati L, Tamura H, Handa H, Czader M, Freeman S, Vyas P, Porwit A, Saft L, Westers TM, Alhan C, Cali C, van de Loosdrecht AA, Ogata K: Multicenter validation of a reproducible flow cytometric score for the diagnosis of low-grade myelodysplastic syndromes: results of a European LeukemiaNET study. Haematologica 2012;97:12091217.

33 Cremers EM, Westers TM, Alhan C, Cali C, Visser-Wisselaar HA, Chitu DA, van der Velden VH, Te Marvelde JG, Klein SK, Muus P, Vellenga E, de Greef GE, Legdeur MC, Wijermans PW, Stevens-Kroef MJ, Silva-Coelho PD, Jansen JH, Ossenkoppele GJ, van de Loosdrecht AA: Implementation of erythroid lineage analysis by flow cytometry in diagnostic models for myelodysplastic syndromes. Haematologica 2017;102:320-326.

34 Haase D: Cytogenetic features in myelodysplastic syndromes. Ann Hematol 2008;87: 515-526.

35 Malcovati L, Hellström-Lindberg E, Bowen $D$, Adès L, Cermak J, Del Cañizo C, Della Porta MG, Fenaux P, Gattermann N, Germing U, Jansen JH, Mittelman M, Mufti G, Platzbecker U, Sanz GF, Selleslag D, Skov-Holm M, Stauder R, Symeonidis A, van de Loosdrecht AA, de Witte T, Cazzola M: Diagnosis and treatment of primary myelodysplastic syndromes in adults: recommendations from the European LeukemiaNet. Blood 2013;122: 2943-2964.

36 Swerdlow SH: WHO Classification of Tumours of Haematopoietic and Lymphoid Tissues, WHO Classification of Tumours, 2017, vol 2 (Revised 4th Edition). 
37 Ogata K, Della Porta MG, Malcovati L, Picone C, Yokose N, Matsuda A, Yamashita T, Tamura H, Tsukada J, Dan K: Diagnostic utility of flow cytometry in low-grade myelodysplastic syndromes: a prospective validation study. Haematologica 2009;94:1066-1074.

38 Mathis S, Chapuis N, Debord C, Rouquette A, Radford-Weiss I, Park S, Dreyfus F, Lacombe C, Béné MC, Kosmider O, Fontenay M, Bardet V: Flow cytometric detection of dyserythropoiesis: a sensitive and powerful diagnostic tool for myelodysplastic syndromes. Leukemia 2013;27:1981-1987.

39 Chu SC, Wang TF, Li CC, Kao RH, Li DK, Su YC, Wells DA, Loken MR: Flow cytometric scoring system as a diagnostic and prognostic tool in myelodysplastic syndromes. Leuk Res 2011;35:868-873.

40 Kern W, Haferlach C, Schnittger S, Alpermann T, Haferlach T: Serial assessment of suspected myelodysplastic syndromes: significance of flow cytometric findings validated by cytomorphology, cytogenetics, and molecular genetics. Haematologica 2013;98:201207.

41 Cremers EMP, Westers TM, Alhan C, Cali C, Wondergem MJ, Poddighe PJ, Ossenkoppele GJ, van de Loosdrecht AA: Multiparameter flow cytometry is instrumental to distinguish myelodysplastic syndromes from non-neoplastic cytopenias. Eur J Cancer 2016;54:4956.

42 Valent P, Horny HP: Minimal diagnostic criteria for myelodysplastic syndromes and separation from ICUS and IDUS: update and open questions. Eur J Clin Invest 2009;39: 548-553.

43 Steensma DP, Bejar R, Jaiswal S, Lindsley RC, Sekeres MA, Hasserjian RP, Ebert BL: Clonal hematopoiesis of indeterminate potential and its distinction from myelodysplastic syndromes. Blood 2015;126:9-16.

44 Kwok B, Hall JM, Witte JS, Xu Y, Reddy P, Lin K, Flamholz R, Dabbas B, Yung A, Al-Hafidh J, Balmert E, Vaupel C, El Hader C, McGinniss MJ, Nahas SA, Kines J, Bejar R: MDS-associated somatic mutations and clonal hematopoiesis are common in idiopathic cytopenias of undetermined significance. Blood 2015;126:2355-2361.

45 Della Porta MG, Picone C, Tenore A, Yokose N, Malcovati L, Cazzola M, Ogata K: Prognostic significance of reproducible immunophenotypic markers of marrow dysplasia. Haematologica 2014;99:e8-e10.

46 Alhan C, Westers TM, Cremers EM, Cali C, Witte BI, Ossenkoppele GJ, van de Loosdrecht AA: The myelodysplastic syndromes flow cytometric score: a three-parameter prognostic flow cytometric scoring system. Leukemia 2015;30:658-665.

47 Chen JX, Mei LP, Chen BG, Wang DL, Luo WD, Luo LF, Lu R, Zheng R, Zhang L: Overexpression of CD200 predicts poor prognosis in MDS. Leuk Res 2017;56:1-6.

48 Westers TM, Alhan C, Chamuleau ME, van der Vorst MJ, Eeltink C, Ossenkoppele GJ, van de Loosdrecht AA: Aberrant immunophenotype of blasts in myelodysplastic syndromes is a clinically relevant biomarker in predicting response to growth factor treatment. Blood 2010;115:1779-1784.

49 Alhan C, Westers TM, van der Helm LH, Eeltink C, Huls G, Witte BI, Buchi F, Santini V, Ossenkoppele GJ, van de Loosdrecht AA: Absence of aberrant myeloid progenitors by flow cytometry is associated with favorable response to azacitidine in higher risk myelodysplastic syndromes. Cytometry B Clin Cytom 2014;86:207-215.

50 Oelschlaegel U, Westers TM, Mohr B, Kramer M, Parmentier S, Sockel K, Thiede C, Bornhäuser M, Ehninger G, van de Loosdrecht AA, Platzbecker U: Myelodysplastic syndromes with a deletion $5 \mathrm{q}$ display a characteristic immunophenotypic profile suitable for diagnostics and response monitoring. Haematologica 2015;100:e93-e96.

51 Voigt AP, Brodersen LE, Alonzo TA, Gerbing RB, Menssen AJ, Wilson ER, Kahwash S, Raimondi SC, Hirsch BA, Gamis AS, Meshinchi S, Wells DA, Loken MR: Phenotype in combination with genotype improves outcome prediction in acute myeloid leukemia: a report from Children's Oncology Group protocol AAML0531. Haematologica 2017; 102 : 2058-2068.

52 Saeys Y, Gassen SV, Lambrecht BN: Computational flow cytometry: helping to make sense of high-dimensional immunology data. Nature Reviews Immunology 2016;16:449462.

53 Aghaeepour N, Finak G; FlowCAP Consortium; DREAM Consortium, Hoos H, Mosmann TR, Brinkman R, Gottardo R, Scheuermann RH: Critical assessment of automated flow cytometry data analysis techniques. Nature Methods 2013;10:228-238.

54 Jafari K, Tierens A, Rajab A, Musani R, Schuh A, Porwit A: Visualization of cell composition and maturation in the bone marrow using 10-color flow cytometry and radar plots. Cytometry B Clin Cytom 2018; 94:219-229.

$55 \mathrm{Ni} \mathrm{W}, \mathrm{Hu}$ B, Zheng C, Tong Y, Wang L, Li $\mathrm{QQ}$, Tong X, Han Y: Automated analysis of acute myeloid leukemia minimal residual disease using a support vector machine. Oncotarget 2016;7:71915-71921.

56 Alaterre E, Raimbault S, Garcia JM, Rème T, Requirand G, Klein B, Moreaux J: Automated and simplified identification of normal and abnormal plasma cells in multiple myeloma by flow cytometry. Cytometry B Clin Cytom 2018;94:484-492.

57 Zare H, Bashashati A, Kridel R, Aghaeepour N, Haffari G, Connors JM, Gascoyne RD, Gupta A, Brinkman RR, Weng AP: Automated analysis of multidimensional flow cytometry data improves diagnostic accuracy between mantle cell lymphoma and small lymphocytic lymphoma. Am J Clin Pathol 2012; 137:75-85.

58 Rajwa B, Wallace PK, Griffiths EA, Dundar M: Automated assessment of disease progression in acute myeloid leukemia by probabilistic analysis of flow cytometry data. IEEE Trans Biomed Eng 2017;64:1089-1098.

59 Aghaeepour N, Chattopadhyay P, Chikina M, Dhaene T, Van Gassen S, Kursa M, Lambrecht BN, Malek M, McLachlan GJ, Qian Y, Qiu P, Saeys Y, Stanton R, Tong D, Vens C, Walkowiak S, Wang K, Finak G, Gottardo R, Mosmann T, Nolan GP, Scheuermann RH, Brinkman RR: A benchmark for evaluation of algorithms for identification of cellular correlates of clinical outcomes. Cytometry A 2016;89:16-21

60 Porwit A, Rajab A: Flow cytometry immunophenotyping in integrated diagnostics of patients with newly diagnosed cytopenia: one tube 10-color 14-antibody screening panel and 3-tube extensive panel for detection of MDS-related features. Int J Lab Hematol 2015;37(suppl 1):133-143.

61 Bardet V, Wagner-Ballon O, Guy J, Morvan C, Debord C, Trimoreau F, Benayoun E, Chapuis N, Freynet N, Rossi C, Mathis S, Gourin MP, Toma A, Béné MC, Feuillard J, Guérin E: Multicentric study underlining the interest of adding CD5, CD7 and CD56 expression assessment to the flow cytometric Ogata score in myelodysplastic syndromes and myelodysplastic/myeloproliferative neoplasms. Haematologica 2015;100: 472-478.

62 Vardiman JW, Thiele J, Arber DA, Brunning $\mathrm{RD}$, Borowitz MJ, Porwit A, Harris NL, Le Beau MM, Hellström-Lindberg E, Tefferi A, Bloomfield CD: The 2008 revision of the World Health Organization (WHO) classification of myeloid neoplasms and acute leukemia: rationale and important changes. Blood 2009;114:937-951. 